Article

\title{
Research by Design: Proposition for a Methodological Approach
}

\section{Rob Roggema}

Faculty of Design, Architecture and Building, University of Technology Sydney, Ultimo 2007, Australia; rob@cittaideale.eu

Academic Editor: Marialena Nikolopoulou

Received: 18 July 2016; Accepted: 6 September 2016; Published: 12 September 2016

\begin{abstract}
In this article, the many definitions of research by design are used to build a coherent model for a research by design process. Three phases are identified, each with their own characteristics and types of activities: the pre-design, the design and the post-design phase. In combination with several practical examples of design-led research projects and design studios, these phases are adhered to practical activities and outcomes. Using all this information, the article concludes with proposing a renewed definition of research by design.
\end{abstract}

Keywords: definition; research by design; research through design; design research; design studio

\section{Introduction}

There are two major arguments why research by design is a suitable yet necessary approach to plan for the future, especially in projects concerning complex environmental challenges.

Firstly, planning the future can no longer be based on the certainty of programmes and conditions. Instead, the planner is confronted with changing conditions and shifting programmes. A plan has also to reflect its own conditions and the effects of the planned interventions. Therefore, the process of planning has to be transformed into a process of multiple feedback. It needs to become reflexive [1].

Secondly, in the current timeframe many problems are complex. Climate change, migration, even economics and social processes, can be characterised as problems with no final solution, which need to be continuously treated and directed to create a better future. These are the so-called wicked problems [2]. There is no single, accepted formulation of these problems. Also, the answers are often defined in "more-or-less" terms in which planners and managers at best can find reasonable, but shifting balances among competing interests and values. The correct formulation of the problem cannot be known until a solution is accepted [3]. These persistent problems cannot be approached with regular thinking. They require counterintuitive thinking, and the development of new knowledge. Design is a very suitable approach for these types of problems [4], because it makes creative jumps in thinking and solving possible. This way, unprecedented solutions and inventions through design innovations come into reach. The approach has already led to a large number of new urban plans, which reflects the uncertainty of urban development [5]. These plans not simply delineate future developments but integrate a large number of partial solutions into a spatial strategy for a city and its suburbs, linking these up with various activities and interventions [6].

This article sets out a practical methodology for how design could be used in spatial research. This is necessary because research by design, as it is often called, lacks clear definitions and sound methodologies. The term design research has become so broadly used in practice without being fully understood beyond the conjunction of design with research, and, particularly in academic circles, it has come to mean widely differing things to different people [7]. Every research that involves design seems to automatically be part of research by design. 
Therefore, this article starts with an exploration of the relationship between research and design, followed by an elaboration on several existing definitions of research by design, after which a method is presented, which is a synthesis of selected design approaches and cognitive processes. This method is based on theoretical observations and not embedded in the practice of design. The case studies in this article are used as illustrations for this method and not as the empirical resources for constructing the method. The article ends with an enhanced definition and conclusions.

\section{Sketch of the Context}

Design and research are two phenomena which some declare to be wide apart. Scientific research is analytical, searching for objective truth and eternal rules [8], aspiring universal application [9], is cumulative [10], and can be validated. However, as Nietsche wrote: "A moving army of metaphors, metonyms, anthropomorphism, in a word a sum of human relations which, increased poetically and rhetorically, were transferred and ornated and which, after having long been practised by people seem to be strong, canonic and common: the truths are illusions which we forgot of, they are metaphors which became shabby and sensually powerless, coins which lost their picture and now are only metal, no coins" [11], the truth is all but crystal clear.

On the other hand, design is described as explorative and innovative, exceeding the limits of the body of knowledge both in a methodological and a theoretical way [6], it is exploring several truths, and studies multiple futures [8], hence it is "non-cumulative". Design is a conversation [12] usually held via a medium such as paper and pencil, with another as the conversational partner [13]. The value of doodle, on the back of an envelope, is an instance of creativity firing the doodler's enthusiasm, personal research and commitment. This circular process is one in which novelty can be generated. Design is both an object of study and a means of carrying out that study [12]. Wakkary argues for designing as "a dynamic process that is improvisational and responsive to the changing design situation" [14].

Design research is both the study of design and the process of knowledge production that occurs through the act of design [15-18]. Design research involves an investigation of strategies, procedures, methods, routes, tactics, schemes and modes through which people work creatively. Design involves the testing of ideas, materials and technologies. It involves innovative conceptual development, product evolution and market modification. It also involves research into cultural, social, economic, aesthetic and ethical issues [19].

In the work of De Jong, several relations between research and design have been identified, depending on the context and the object (Table 1). He distinguishes "design research", "typological research", "design study" and "study by design" [20]. Design research may concern determined objects (Table 1) within determined contexts, but designs differ per definition and the context will always differ and change. So, other kinds of design-related study vary either the object (design study) or the context (typological research), or even both (study by design, see Table 1):

Table 1. Types of design-related study [21].

\begin{tabular}{lll}
\hline CONTEXT & & \\
\hline Determined & Design Research & Design Study \\
\hline Variable & Typological Research & Study by Design \\
\hline & Determined & Variable \\
\cline { 2 - 3 } & OBJECT & \\
\hline
\end{tabular}

Design research is evaluating the study of completed designs. It describes and analyses existing designs with a known context, often or implicitly in the form of comparative study. 
Whenever an identical architectural form, structure, operation, technique, function, performance or concept is recognised in different contexts the notion of a category or "type" is involved. The study of such context-independent types, their use in the making of designs, is called typological research.

A specific context contains fields of related problems and aims to be solved in combination. It has to produce new possibilities bringing together the many desirabilities and probabilities of stakeholders and specialists into a concept. Designing, decision-making and research are different modes of inquiry and different kinds of language in the team. Anything probable is possible by definition, but not all possibilities are also probable. That mode of improbable possibilities is the core of design study.

Characteristic for study by design is generating know-how and understanding by studying the effects of actively and systematically varying both the design objects and their context.

Research in (art and) design can be organised into the following three categories [22-24]:

Research into (or about) design is the most straightforward research practice in art, design and architecture. This is historical, social, technical, material research, with countless models from which it derives its rules and procedures. This is similar, but not the same as, science of design [25];

Research through (or by) design is a material-based research, development work and action research: practical experiments in laboratories resulting in reports and step-by-step diaries, clear about what is being achieved and communicated through the activity of design process. It has similarities with design science [25].

Research for design is development work whose end product is an artefact, where the thinking is embodied in the artefact and the goal is not primarily communicable knowledge in the sense of verbal communication. Is similar to scientific design [25].

The main question is how research could emerge through design and new knowledge can be harvested using methodologies and processes of designing. Design is continually weaving between inquiry and proposal and involves values about aesthetics and beauty, which are hard to be assessed through general research indicators or criteria.

\section{Definition of Research by Design}

Research by design is a type of academic investigation through which design is explored as a method of inquiry, by the development of a project and also exploring the different materials by which a design is carried out-sketches, mapping, among others [10].

Research by design, Hauberg calls it a strategy [23], is used to describe the various ways in which design and research are interconnected when new knowledge is produced about the world through the act of designing. The methodology aims to generate desirable, maybe unexpected, urban perspectives in place of probable, but less desirable, urban developments [26].

Slightly different from research by design, but very similar to, research through design [22] is defined as a designerly inquiry focused on the making of an artefact with the intended goal of societal change [27-29]. It is the process of iteratively designing artefacts as a creative way of investigating what a potential future might be [30]. Both research by and through design differ from research about (or into) design, e.g., research about the design process, and research for design, focusing on improving design practice [31]. Research through design favours a constant realignment of the construction of artefacts, based on trial and error, to better tackle complex design problems [32]. "Research through design" projects have two underlying dimensions of "looseness" and "openness" [33]. Looseness refers to the number of outcomes targeted or allowed by the project and the designers/researchers. Openness, on the other hand, relates to how "secret" the project is. An opened project can allow public participation, media attention, etc.

In architecture (landscape architecture, urban design), design is an essential feature. Any kind of inquiry in which design is a substantial part of the research process is referred to as research by design. In research by design, the architectural design process forms a pathway through which new insights, knowledge, practices or products come into being. It generates critical inquiry through design work. Therefore, research results are obtained by, and are consistent with, experience in 
practice [34]. Research by design produces verbal and non-verbal forms of output and discourse proper to disciplinary practice that make it discussable, accessible and useful to peers and others. Research by design is validated through peer review by panels of experts who collectively cover the range of disciplinary competencies addressed by the work [23].

Spatial design is no longer just a plan, but at the same time has become a tool for the exploration of the potentials of the site and a means of communication and negotiation between parties involved. The traditional order, first research, then defining a programme and finally making a design is, at least partially, turned on its head. The process of planning has lost its linear character and has transformed into a process of multiple feedback [6]. Space does not only make intended use possible, but it is also offering and giving rise to new and unexpected forms of use. Function follows space [35]. Here it identifies two major manifestations of research by design [6]:

(1) It takes place in the search for a suitable site for a given or desired function in which advantages and disadvantages of different sites are evaluated by means of design.

(2) It occurs when designing is used as a means of exploring the spatial possibilities of and developing a new programmatic infill for a given site.

\section{Towards an Integrated Model for Research by Design}

As mentioned above, design is extremely suitable for dealing with wicked problems, problems that require constant adaptation. Design provides adaptation to individual systems, hence changing existing situations into preferred ones [36] or improving the quality of life [37]. This "defining how things will be", the real, is intrinsic to both the research objectives and the design goals of research through design [38]. Several scholars have expressed this in the 60s in slightly different ways. Alexander [39] emphasises that "Scientists try to identify the components of existing structures, designers try to shape the components of new structures". Similarly, Simon [36] states "The natural sciences are concerned with how things are...design on the other hand is concerned with how things ought to be." This distinction between existing and new is reformulated, linking science to analytical and design to the constructive realm in the writings of Gregory [40]: "The scientific method is a pattern of problem-solving behaviour employed in finding out the nature of what exists, whereas the design method is a pattern of behaviour employed in inventing things...which do not yet exist. Science is analytic; design is constructive".

Because many design methods depend on the context [41], in this article an abstract method is presented, in which it is easily possible to include situational aspects in order to distil a context-specific method for each design question or problem. The abstract method has been inspired by earlier descriptions of theoretical models of design processes. The method will be constructed in subsequent distinctive steps.

As the basis for the model, a simple yet fundamental distinction between analysis, projection and synthesis ([42]; Figure 1) is taken. During the analysis the way things currently are (the truth) is researched, while the projection is concerned with how things could be (the ideal). In the final stage of the research, the synthesis is concerned with how things will be (the real).

According to Milburn and Brown [43], five models explain distinct approaches of incorporating research into design. These are the artistic, intuitive, adaptive, analytical and systematic models. They all have a pre-design research phase (Figure 2) that educates the designer about similar sites or potential solutions, a phase that resembles the analytical stage. Fitting with the phase in which potential design solutions are projected, research needs to be drawn into the design process, as is consciously undertaken in the adaptive, analytical and systemic models. In the final parts of the same phase, research is used to assess, prioritise, judge and modify their design solutions. Most of the literature-based research lacks this function. In each of the three phases there is an interactive approach to problem solving, e.g., exchange between both research and design and researchers/designers and the wider audience. 


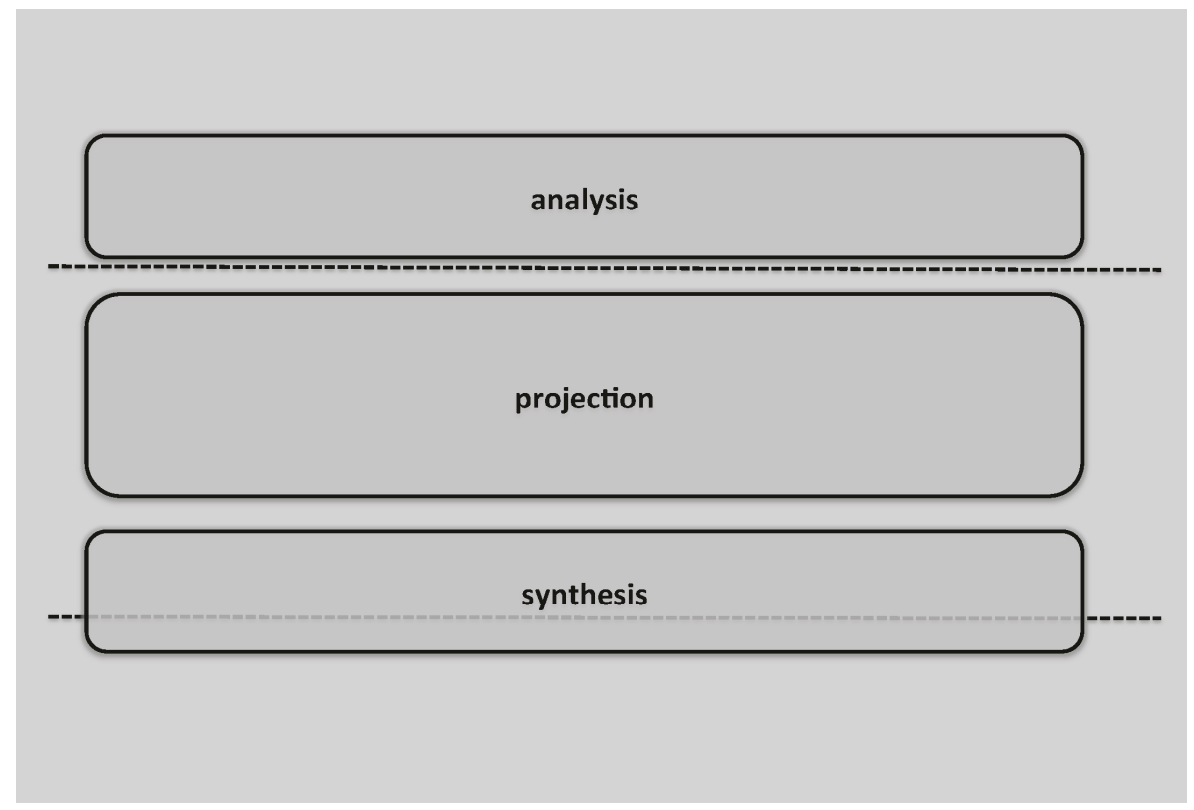

Figure 1. Analysis, Projection and Synthesis.

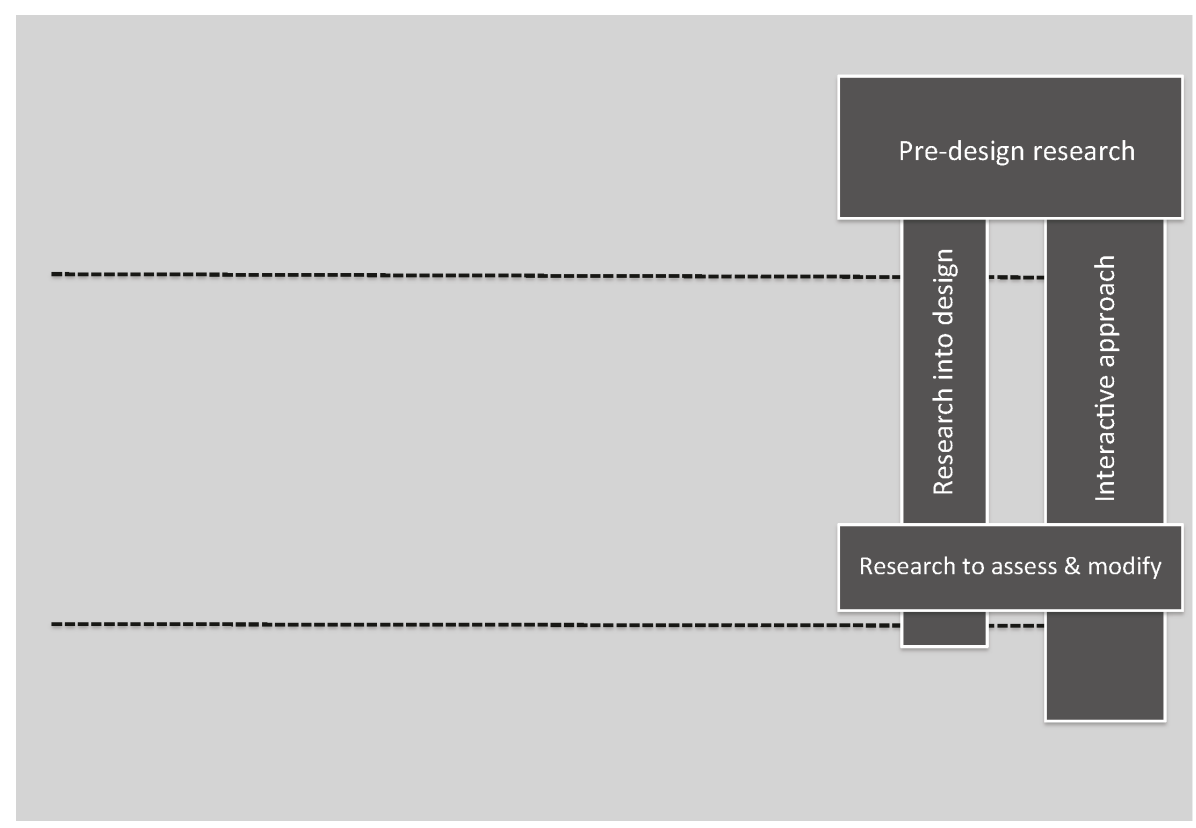

Figure 2. Predesign, Research into design, Research to assess and modify, Interactive approach.

When these three phases are further "filled" with a typical focus of the research to be undertaken, in the analytical phase, research by design should demonstrate, according to Lima et al. [44], a question to be addressed (Figure 3). What is the question and how/why does the author intend to address it. The projection is then the phase when adequate answers to the formulated question are sought, using non-textual artefacts to reach the adequate answer to the formulated question. The final stage, synthesis, brings forward the outcomes of the research, but also delivers a knowledge transfer and has a wider impact. The use of non-textual artefacts reach outcomes that would not be reached by other means of research, the knowledge generated by the non-textual artefacts is reportable and transferable and the use of non-textual artefacts achieves goals that are of interest of a wider community. 


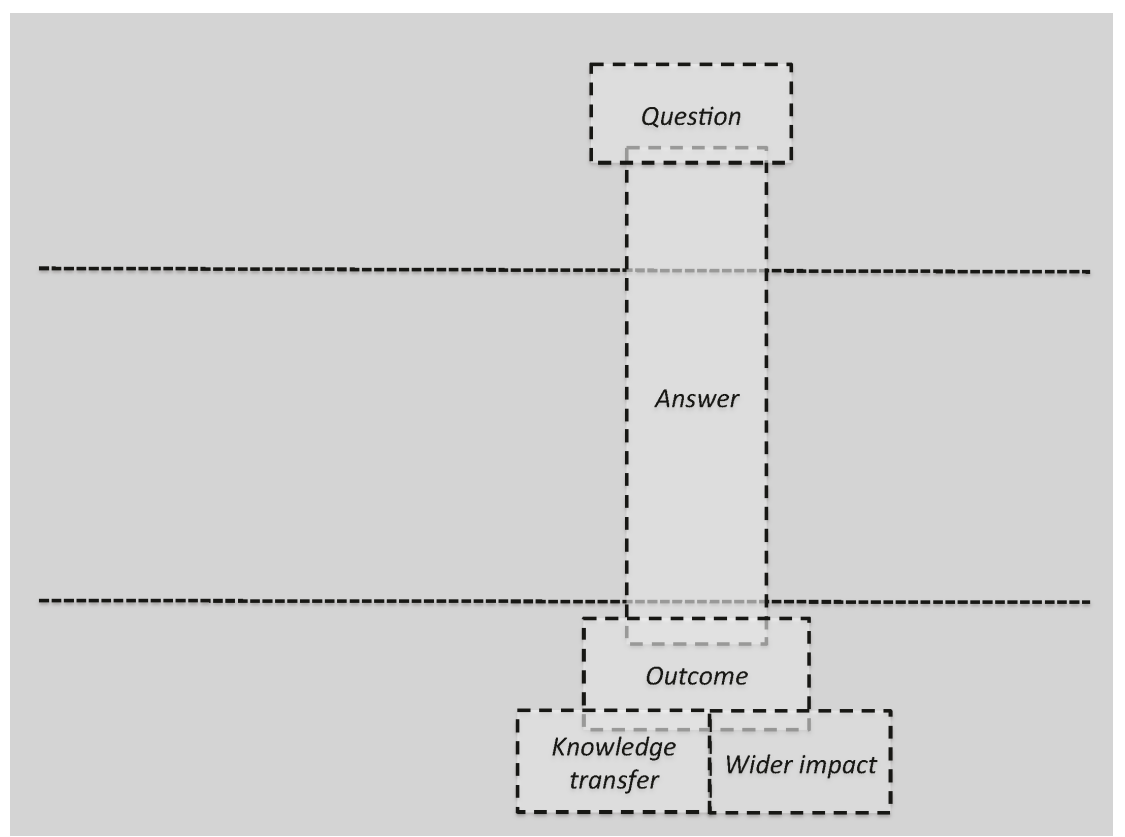

Figure 3. Question, Answer, Outcome, Knowledge transfer and Wider impact of research by design.

Elaborating on this, the first stage of research by design focuses on the basic perceptions and the investigation (Figure 4). These are the first two of six elements of research by design [23]. The basic perceptions are philosophical, ethical and theoretical perceptions, norms and values regarding the surrounding world, the role of (landscape) architecture and the object itself (landscape architecture). These are a prerequisite (paradigm) for the research process and may be discussed and, in part, advocated, possibly as basic research. Under the investigation, the regular elements at the start of the research by design project, i.e., analysis, criticism, selection and problem formulation, are counted.

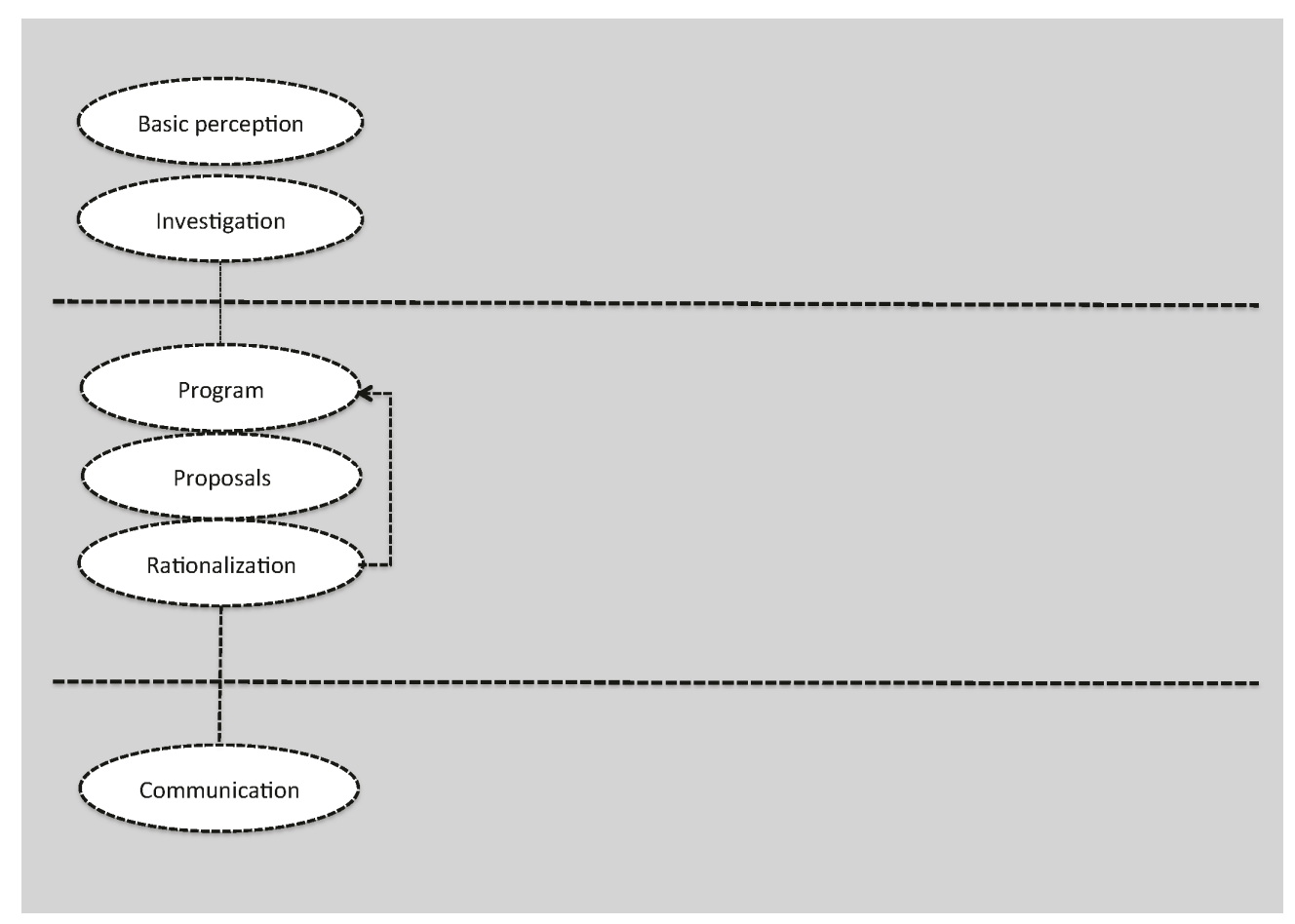

Figure 4. Perceptions, Investigation, Programme, Proposals, Rationalisation and Communication. 
Programme, proposals and rationalisation belong to the second phase of projection. The programme consists of the actual problem, the definition of partial assignments and the goals within an overall programme (rules and norms). This can take the form of strategic research. Out of this programme, proposals are to be developed in the form of a concrete, spatial proposal as a possible response to the programme. This is an experimental and partially independent aspect. The last element of this phase is the rationalisation, which provides the argumentation, the theoretical explanation of the proposal and subsequent testing in practice, if applicable. The results of the rationalisation may be led back to the programme, which then can be adjusted to follow the cycle again, leading eventually to new proposals and rationalisation.

In the last phase communication takes place. The material is presented in a synthesised form in a text, a drawing, a model or an example that explains the correlation between the components of the methodology in a manner that is consistent, reasoned, made probable and cannot be contradicted.

Each of the three phases is characterised by its own dynamics (Figure 5). Following Basballe and Halskov [45], in the first stage coupling determines a research trough design project. Coupling is the initial step that "unites research and design interests" [45]. During coupling, the basic frame and constraints of the project to serve both levels of interests are established. The second stage of a research through design project can be characterised by a dynamic of interweaving, when research and design interests influence each other and the project, as processes, methods and validation are established. Decoupling appears at later points of the project when the designer/researcher must focus on one of the interest sets (design or research). For example, decoupling appears during the production phase since it focuses on the design process, but is also appears during the final evaluation and inquiry when the research interests become the focus of the work.

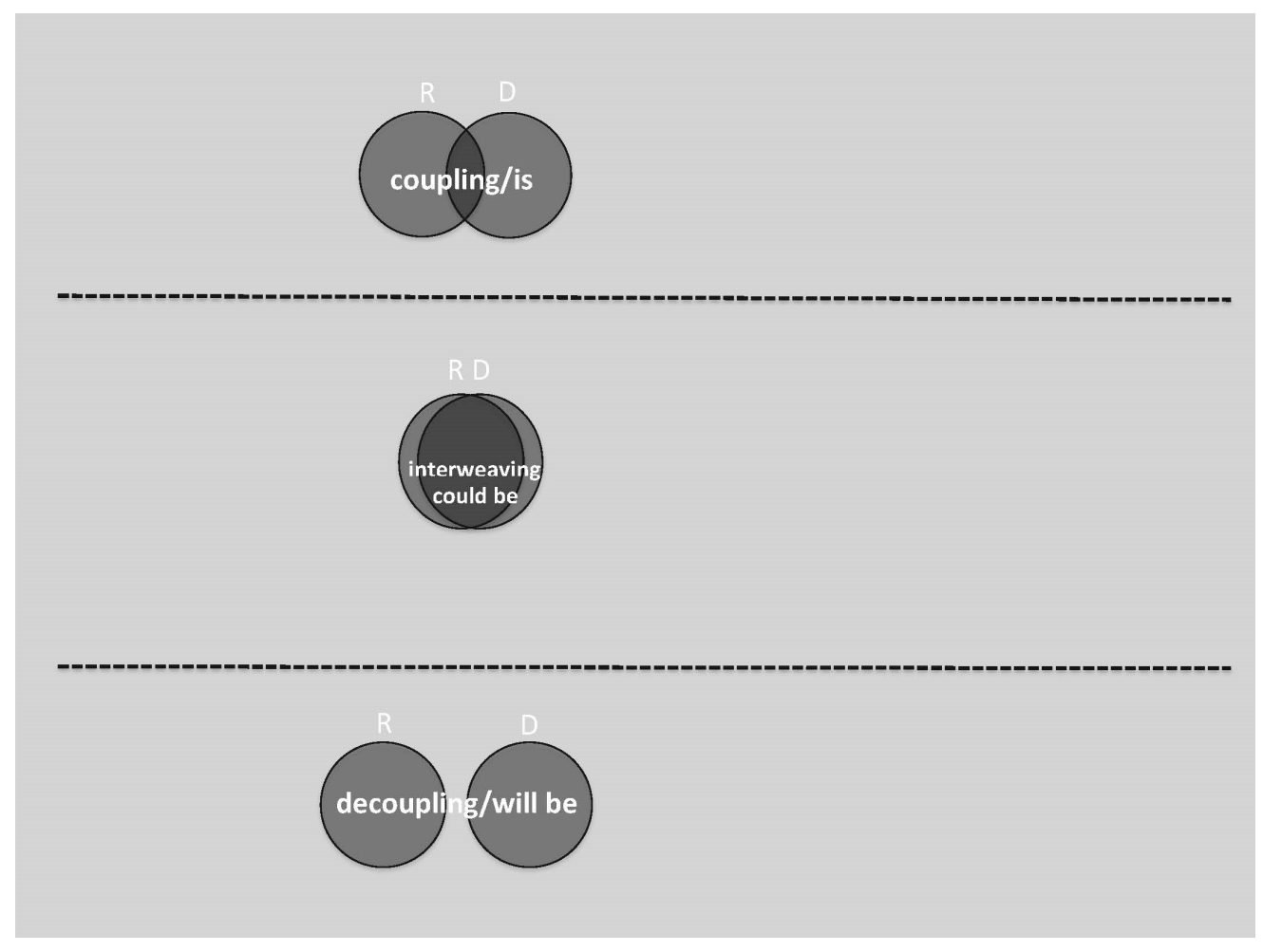

Figure 5. Coupling, Interweaving, Decoupling.

With the background of these five theoretical models, and after combining and integrating these diverse aspects, an interrelated method for research by design arises (Figure 6). This method divides the process in the three phases, within each of these phases the typical characteristics are as presented in their parts above. 


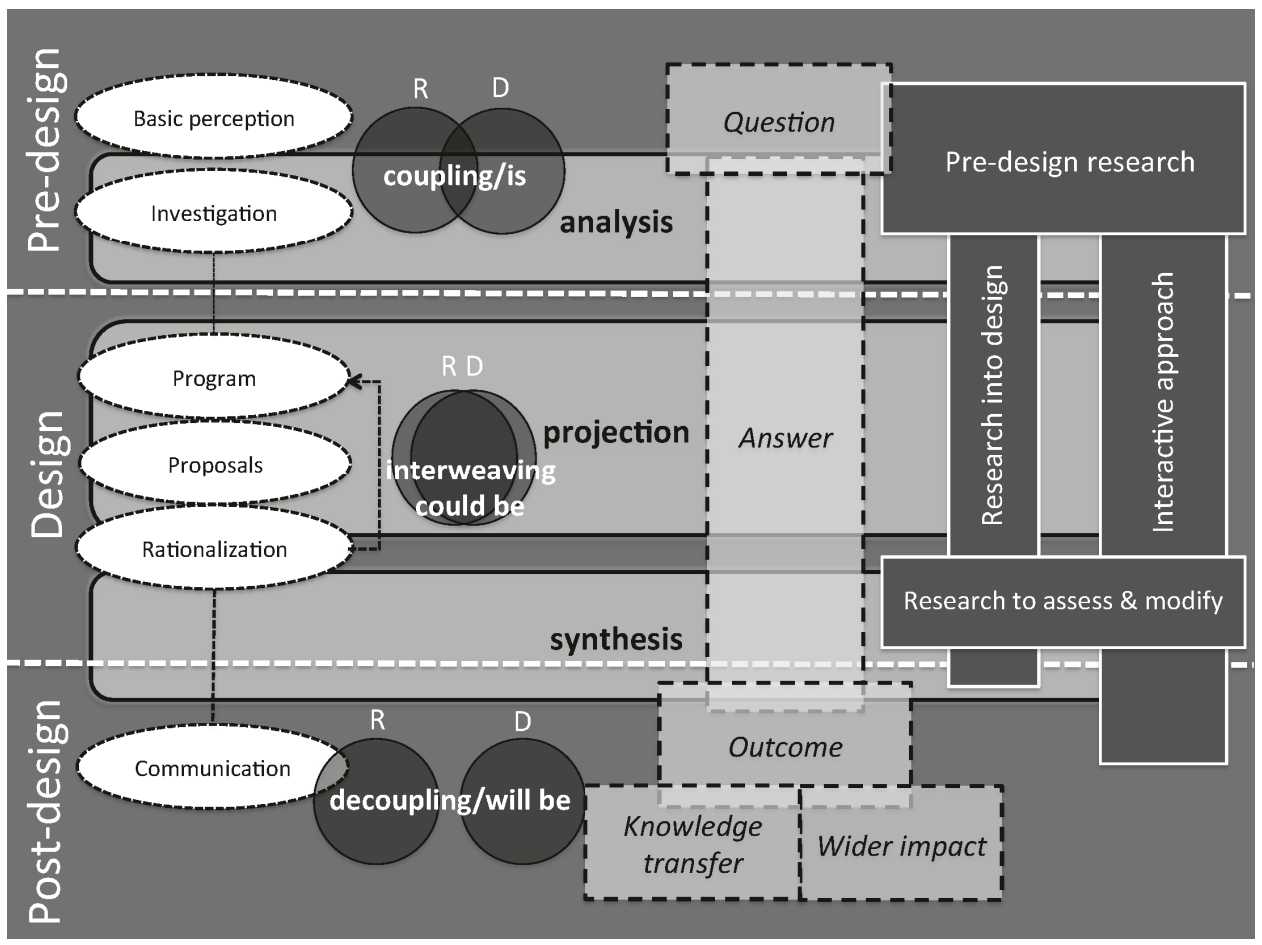

Figure 6. Combined approaches of research by design.

In this figure three overlapping phases of research by design can be distinguished. A pre-design phase is followed by design and post-design phases. In each phase both research and design are important components. Each phase connects conventional design stages with cognitive processes, derived from the different theoretical descriptions mentioned before. It leads to a three-staged method which can be used in design practices, design studio practice and design-led research. Every new design project can rely on the three-staged method and use the characteristics that are part of each phase in order to construct a fitting process or project design.

This method will now be further described and illustrated with existing research and design projects. The case studies are used only to deepen the understanding of the distinguished phases, and were not used to construct the method.

\section{Pre-Design Phase}

The first stage of a research by design process is characterised by understanding. Research is carried out prior to the actual designing. This pre-design research aims to bring a basic perception about the question in play and starts the analysis and investigation of task, context and potential avenues for research and design. In this phase interactivity already starts with connecting to end-users, stakeholders and experts. Research and design are coupled, meaning the explorations on the actual design question are undertaken through analytics, but also in a designerly way. When research is brought into the pre-design phase it provides insights into potential answers and future design directions.

One of the first challenges for a researcher/designer will be to verify that the problematic situation is indeed a wicked problem that requires a design inquiry approach, and not a simple problem that can more effectively be addressed through scientific or engineering methods of inquiry [30]. 
The inquiry carried out in the Floodable Eemsdelta case [46-48] illustrates this. At first it has been investigated whether the design problem is actually a wicked problem. Given the rising sea level and the uncertain threats to the landscape, such as the potential of an unprecedented storm surge, it was concluded the problem is of a complexity that justifies a wicked problem approach. In this phase the ambition for this area was set to create a resilient landscape able to deal with unexpected flooding.

The second step was to collect information regarding the qualities and (historic) characteristics of the area, but also about the programmes, policies and expectations. In the Eemsdelta case study most of this information was mapped. Besides the regular mapping on elevation, topography, water, land-use and urbanisation, amongst others, maps were produced to give (spatial) insights into the existing policies, the status of coastal protection, climate data \& risk, existing qualities of the landscape and an historic understanding of the genesis of the landscape.

\section{Design Phase}

The design phase forms the heart of the research by design process. The interactive approach is continued and intensified, with exchange with end-users, stakeholders and experts. Also, in this stage research is continuously brought into the design process and deliberations. Research and design are closely interwoven. Design is a reflective practice in which critical assessment, comparability and evaluation takes place through sketching, through the continual weaving between problem and solution in an iterative movement between inquiry and proposal [49]. Here the designer is a researcher in a practice context. In Schön's "reflection-in-action" the designer/researcher is not dependent on structures such as established research theory requiring verifiable/proven techniques like representative case studies, but is able to construct a new research theory about a unique case through the design work. Instead of separating thinking from doing, the designer/researcher integrates implementation into the nature of inquiry. It is the way this process occurs in the design studio that can provide research potential. Unlike most research paradigms, it is useful in situations of uncertainty or uniqueness because it is not constrained by the dichotomies of technical rationality [50].

In the design process the potentials of how the future could be are projected and answers are sought for the design problem. Based on the programmatic demands, a suite of proposals are developed and rationalised. The design options are assessed and modified in an iterative and reflective process. Towards the end of this stage syntheses are being explored and critically reviewed.

Three different design research projects illustrate this phase: the Floodable Eemsdelta in the Netherlands, the SWELL and KINDLE design studios, carried out in Victoria, Australia and the design-led research project, also conducted in Victoria, Australia.

\subsection{Floodable Eemsdelta}

In this case study [46-48] the Swarm Planning methodology $[48,51,52]$ has been applied. In this process, the largest uncertainties have been identified first and are subsequently used as the point of departure for the design process. At this stage it is essential to create the freedom of thought to be able to identify a counterintuitive invention which could accommodate the paces of change and uncertainties. An exploration in all directions, developing typologies and a range of potential scenarios in a creative process, supports this. In the case of Floodable Eemsdelta the invention was to create a small gap in the dike, which allows seawater to enter the hinterland. This intervention anticipates an eventual storm surge or flooding, because it literally let the water intrude, not by surprise but in a well-controlled and predictable manner. Doing so, the design makes use of the powers of nature, by which the resilience of the system can be enhanced. In the design propositions the impacts of these interventions, i.e., required spaces could be anticipated.

The next step has been to confront, in a first assessment and review, the design propositions with the context. They were tested on their impact on the landscape, whether they contain new opportunities and if the propositions solve more than one problem. The objections against the initial proposition were, for instance, that it is impossible to flood the landscape, it is unsafe, it is unclear where the 
people need to move, there will be a loss of economic value, the present coastal protection is sufficient and that farmers in the area do not want this. The design propositions could then be improved. The slow process of seawater brings also sediment, hence the ground level rises. The designs could emphasise the spatial quality of living in a natural, water-rich environment, adding economic value to the area. Moreover, the area becomes safer, as the potential sudden flooding is already occurring in a controlled way. The impact and change it can bring in the current landscape is visualised and critically reviewed. After this divergent phase in the process, the propositions were again redesigned and the urban environment level was shaped accordingly. The way people could live and build houses in the landscape (floating and on higher, artificial hills), has further been detailed. Again, these propositions were critically reflected upon. The main concerns in this step were how people could reach their houses and how facilities such as sewage and electricity could be arranged.

In the final convergent step only a few proposals remained, as a first step in the synthesis process. Based on the case study results, some new insights could be concluded. It is possible to slowly transform the landscape and stay safe, to add new qualities for living (in a further shrinking area) and the proposals have "multiple solving power": they bring safety, deal with shrinkage, add spatial quality, additional housing and an alternative for agriculture in the form of aquaculture.

The research in the Eemsdelta case brought new knowledge on design options to the table. Instead of progressing identical solutions to protect the land against storm surges, the design alternatives sparked counterintuitivity and through this insight into how the anticipated flood could be accommodated and "welcomed" in the hinterland. It lead to new propositions for the landscape, in which water played an important role and the landscape can be formed by the powers the water brings. The threat of the storm surges and sea level rise informs the design and building with nature principles [53] strengthens the resilience of the area. During the design process a continuous interchange of knowledge and understanding between the research and the design process took place. The benefit of this was that the design options could pose new questions to research and research outcomes could be valuated through the spatial impacts and benefits they would bring.

\subsection{The Design Studio}

The design studio is, besides a teaching environment, also seen as a platform for research, for instance, to use for education research or as a creative work in itself. When design studios are used as part of a larger research programme students and tutors may engage in a research partnership of mutual problem investigation, in which the studio provides a forum for speculative ideas taken through to a degree of resolution. In this way, the design studio provides a particular space where, through a range of design processes, propositions about place, culture and the environment can be explored using a range of media to render the propositions into abstract form. Design studios could be the space in which speculative ideas about contemporary urban issues could be explored as designs, creating an unusual but valuable contribution to the wider body of knowledge [54].

Considerable planning is needed to design the studio as a research project, paying special attention to both the broader research issues and the detail of the studio brief. In a refereed studio [55] the findings are to be academically appraised and presented in a rigorous way.

The studio is a process of inquiry, an intensive journey with a high level of production, but where none of the design propositions are intended as an end-result, nor a conclusion, but rather a continuously evolving instrument to interrogate the issues and opportunities at stake. It is a process in which the acts of analysis and design are turned around, mixed and blurred into a situation where at times it might even be hard to distinguish between both. However unconventional it may appear, it is the experience that the more "personalised", interpreted way of mapping does not only give clearer focus in research but also functions to bridge the gap between research and design as separate disciplines. This approach does require a close monitoring from the design tutor of the work to avoid loss in efficiency and a random, pointless sprouting of ideas. The process as such has a rather more iterative nature where design and analysis are constantly interrogated and reframed. The mere 
ability to "drift" in a parcours of trial and error opens up the possibility for surprise, discovery and potentially innovative thought, but at the same time the uncertainty of production in terms of quality and quantity. The studio aims to welcome, enable and enhance this process by constantly readjusting its course itself. The exact structure of the studio, as well as the deliverables, are only roughly set out on beforehand, with enough flexibility to anticipate and accommodate new ideas. Being intrinsically non-linear, and not necessarily converging towards "solution", the end-result is more a documentation of a process than a conclusive report. Its aim is primarily to feed and contribute to the debate rather than to offer a master plan or blueprint. It is an exploration and testing of ideas by means of design. Design is both method and outcome. It is the instrument to generate ideas, and to test and communicate them. Design might precede analysis. It may start as a gut-feeling and can be "post-rationalised" by research [10].

The process of two design studios, KINDLE and SWELL, part of the Landscape Architecture programme at RMIT in 2011 and 2102, are used here to illustrate how the design phase of research by design is made operational. The subject of the Kindle studio was how to create a resilient landscape for a bushfire-prone area, in this case the Bendigo region in north-western Victoria that is resilient. The Swell studio asks the same question for an area prone to storm surges, Hobsons Bay, situated along Port Philip Bay, close to Melbourne.

\section{KINDLE and SWELL}

In both studios the pre-design phase consisted of making a suite of information regarding the landscape, socio-economic factors, the water and ecological systems, climate change and risks and policies and assessments available to the students. Moreover, in the first stages of the design studio, the design objective was made crystal clear: the students needed to respond to an unprecedented and unpredicted swell in their landscape and urban designs for the coastline and hinterland of Hobsons Bay. The objective in the Kindle studio was similarly challenging: the students needed to design an urban landscape capable of adapting to and even welcoming severe bushfires in a way people could live in a safe and enjoyable environment.

In the design phase the students were given freedom to explore design propositions in any direction they deemed interesting, fruitful or promising. Literally, they were let out to swarm and circle around the information available, the site, and expectations of themselves, their peers and the supervisors. This led to a suite of dynamic landscapes in which the natural forces of water or fire drove the landscape interventions and urban designs. Many of the students came up with a proposal, which included time as a serious factor, creating environments that have the capability to change.

Subsequently, the students were critically questioned on the meaning and impacts of their design propositions for the problem, as well as the consequences of their ideas for the potential qualities and opportunities for the area.

After this, a process of continuous redesign, review and questioning and redesign took place, during which new questions and objections were placed and the design propositions were enriched.

In the SWELL studio this has led to concepts that connect the underwater topography with the urban landscape [56]. This way the coastal zone as a whole starts to act as a protective zone, capable of dealing with storm surges, improving the underwater ecology and creating interesting urban environments on land (Figure 7). 


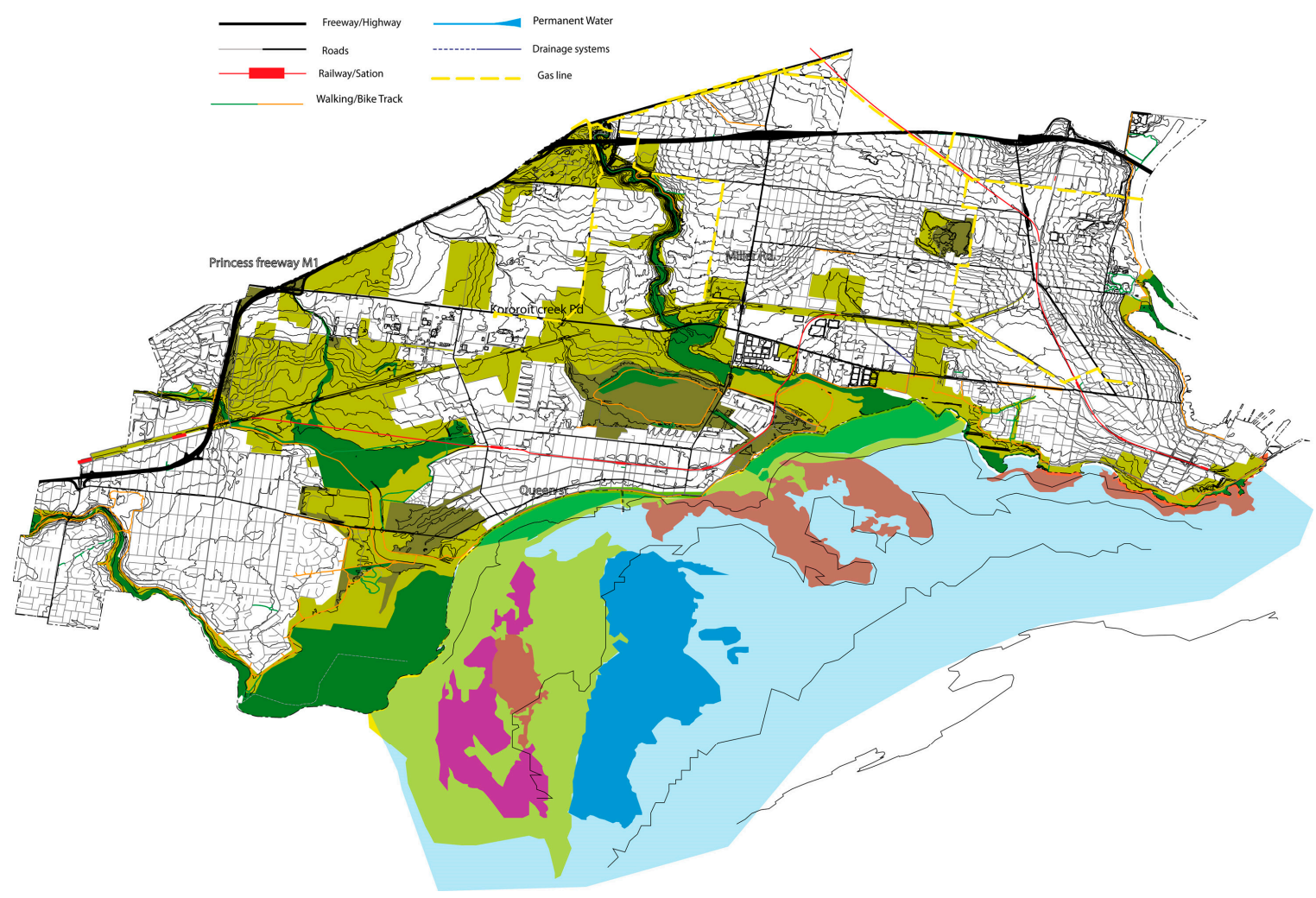

Figure 7. Connected topographies of Hobsons and Port Phillip bays [56].

Another approach in dealing with storm surges is to strategically retreat [57]. Taking the underlying landscape as a point of departure, the configuration of a retreated town appears. Intrinsically this determines the safe and risky areas, and the urban form (Figure 8).

In the KINDLE studio, the urban fringe of Bendigo is transformed into a protective fireproof edge [58]. By replacing houses that eventually burn with concrete pillars, a shield emerges, which holds back new bushfires. As a result of this, new housing is planned at the lay-side of town, de facto moving Bendigo slowly eastward.

As a final step in the studios the design propositions have been critically reviewed and appraised. Criteria used to assess the designs were focused on research quality, such as the documentation of the research process in visuals and findings, and a reflection of independent questioning by the students themselves, and also on the design quality through assessing the materialisation, the used tools and techniques, presentation and contextualisation.

On the basis of the studio process and the improvements of the propositions it can be concluded that the students showed a vast increase in learning and performance. Besides, there could be novel findings distinguished about the site and its broader context through unsuspected views and new knowledge. Moreover, the qualities of the designs, in terms of counterintuitivity, rigour, innovation, spatial dimensions, applicability in similar cases and how (not if) the objective is met, have been up to standard and in many cases better than that.

Both design studios started off with an open question, which the students transformed into a design problem and question. The students explored new information with new research methods, such as modelling the flooding in a landscape and meanwhile adjusting the design parameters and mapping uncharted territories, such as the connecting between sea and land and "cross-sectioning" the area, linking the analyses of each cross section back to one whole. The research into resilience phases (according to [59]) and combining this with swarm planning principles, led to new spatial typologies of the landscape, which guide land uses and future developments. Additionally, counterintuitivity and working with nature in both the KINDLE and SWELL studio, led to new design options for 
developing the urban layout, shielding the town and retreating the city. The research, undertaken to discover the vulnerabilities and resilience of landscape and urban systems, led in these cases to unprecedented propositions.
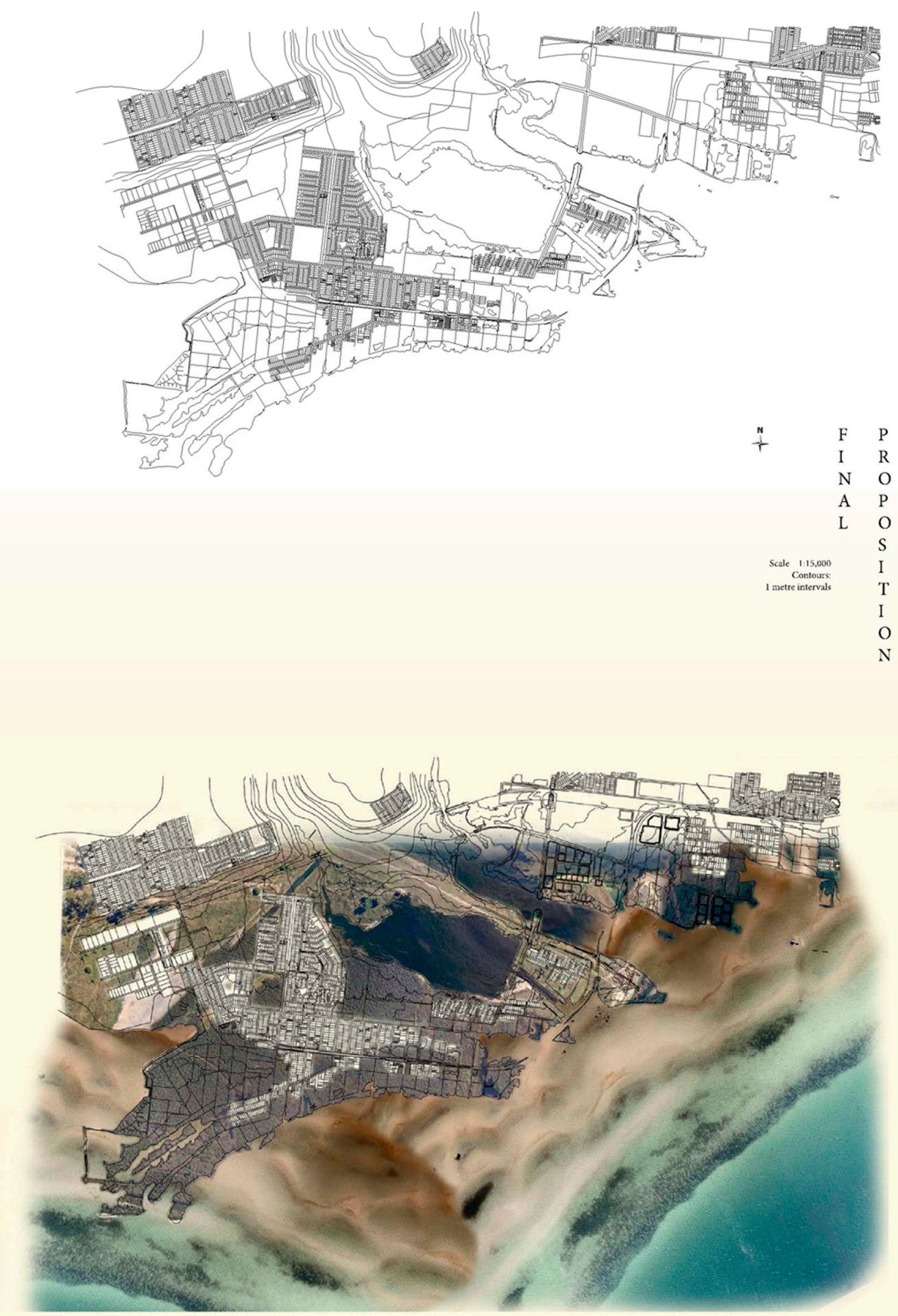

Figure 8. Retreat of Hobsons Bay [57]. 


\subsection{The Design-Led Research Project}

In the project design-led decision support for climate adaptation in regional Victoria [60], two regional towns in Victoria were taken as case studies for a design process, together with local communities to support their spatial adaptation to climate impacts. In this research project the case studies were taken as the object of research, looking at both the process and the content of the design proposals. Two consecutive design charrettes [61-64] were carried out in two towns, Bendigo [65] and Sea Lake [66].

Before the first charrette, a design brief $[67,68]$ was put together in which basic information and mapped analyses about the context, the existing landscape, the design task, programme and participants was collected.

The first, three-day charrette aimed to identify a broad pallet of design solutions that are capable of dealing with future climate change and uncertainties. Teams worked in a creative and reflective process via brainstorming sessions, sketching, presenting intermediate proposals, further sketching, plasticine modelling and presenting final designs and on preliminary spatial propositions, which are both developed and supported by the participants. At the end of the first charrette a first quick appraisal was carried out. Participants could support or decline elements of the different propositions using pro- or con- post-its [69].

The outcomes were then refined. The proposals were designed in more detail, omissions were taken out and details were added. Together with the quick appraisal these results were then assessed on social, ecological and economic metrics [69].

The results of the appraisal then informed the second, two-day charrette, which aimed to converge the material into one or two integrated designs. In this charrette the teams worked collaboratively towards what they commonly believe to be an ambitious and realistic spatial pathway for the future. The final output of this second charrette is an integrated design and a spatial strategy with catalyst projects, ready to realize.

The criteria for refereeing a studio would be consistent with any assessment of research findings or, in fact, any design critique. Criteria used could, for example, be the clarity of objectives, relevance and insight, a creative and innovative process and presentation and coherent, original and fruitful outcomes [55].

In the design-led project new knowledge came to the fore through the intensive interaction with local communities in the design process. The academic information was made available to the local communities through sensitive mapping and visualisation of climate data in order to permanently make this information understandable and applicable in the design process. This information was brought to the communities in verbal forms and visualisations on maps and charts. Moreover, the communities were supported in their design capabilities through the use of tactile working methods and means, such as interactive sketching in groups and collective 3D modelling with plasticine.

\section{Post-Design Phase}

In the post-design phase the results are the final syntheses of the work, which need to be coherently presented. The results show how the future is seen, and what that future will be. The impact for a wider community, both academic and social, needs to be made manifest and the new knowledge, developed during the design process, becomes available for a wider audience. This requires a strategic and conscious communication. The interactive process ends here, as the people and partners involved in the design process are jointly responsible for the end products, but will split up at the same time. This does not mean there is no interaction anymore. Only this will take place with new groups and consists of communication and discussion with the broader "outside world". In this phase, research and design are decoupled. On the one hand, the design results are presented in reports, panels, drawings and schemes, while on the other hand, the research outputs follow the route of academic publishing and debate. 
Whilst the designs of the design studio have their own merits and are judged accordingly, the design studio as a whole is taken as an academic product, and reviewed on the basis of its methodology, research question and findings. Some of the results may be used as illustrations in publications, such as designs from the KINDLE studio, as an underpinning of a research theory [70].

The outcomes of the design-led project find also their twofold ways. On the one hand, the propositions are presented to the community as designs: how the future could look like. On the other hand, in several academic outputs, observations and descriptions of research methodology and findings [63,71,72] are harvested.

The results of the Floodable Eemsdelta case study also have two types of impact. First, it has, partly, been taken up in regular policies, such as the regional plan for the province of Groningen, in which the so-called broad dike concept was introduced [73], and the national Deltaprogram [74]. This will eventually lead to realisation of (parts of) the design. Secondly the swarm planning methodology used in the Floodable Eemsdelta design, is subject of a suite of academic publications, conference presentations, academic lectures and additional workshops (amongst others: $[46,48,75,76])$.

\section{Definition}

Discussing the broad spectrum of definitions of research by, through, into, about and for design, and the concrete experiences in design studios and research projects, a renewed definition of research by (or through) design can be given:

"Research by design is a method, which uses design to research spatial solutions for a certain area, accommodating a design process, consisting of a pre-design phase, a design phase and a post-design phase, herewith providing a philosophical and normative basis for the design process, allowing to investigate the qualities and problems of a location and test its (spatial) potentials, meanwhile creating the freedom to move with the proposals in uncharted territory, and producing new insights and knowledge interesting and useful for a wide audience."

This definition aims to unify perspectives from research by design theories and scholars, but given the ambiguous nature of the subject, it is hard to formulate a definition that meets the broad spectrum of perspectives taken by the many scholars and practitioners around. However, this definition marks some crucial aspects of a design process:

- It should be embedded in the local, cultural and political context

- It should allow for unexpected explorations in order to identify best fitting solutions for a design problem

- It should emphasise the development of new knowledge and be beneficial for a broad public.

These key elements of a design process are embedded in the method proposed in this article, in its abstract brought down to three phases from pre-design, design, to post-design.

\section{Conclusions}

In this article, a range of definitions and theoretical reflections have been discussed and integrated into an abstract method for research by design processes. This model consists of three overlapping phases: pre-design, design and post-design. In each phase research components and design activities mingle. However, in the pre-phase research and design are coupled, during the design phase they are interwoven and in the post-design phase they are decoupled.

The core elements of a research by design approach are a continuously interactive setting, in which participants in the design process are placed in the position to creatively exchange, collaborate and develop new knowledge together. In each stage research is brought into the design process, in the beginning with a focus on what is there, analytical. The second stage is characterised by what could be there, and is of an explorative nature. The final stage is reflective on what will be there.

The method is abstract yet detailed with characteristics, as shown in Figure 7. This combination of abstract and concrete elements makes it possible for future design research projects to detail and 
specify a design process fit for the purpose. Because the examples given for the different phases must be seen as illustrations, the "proof-of-the-pudding" of the method still remains. This could be a new avenue for future research. The question of how to apply, and which diversity of application of this method is possible, is an interesting question for future research.

Several conditions for a successful research by design process can be given:

(1) To start with a challenging, even "impossible" and complex design task, whilst at the same time without formulating criteria for "good" solutions beforehand.

(2) Create an atmosphere where the freedom is felt in the design process to go anywhere with design, and allow participants to swarm with their thoughts in any direction.

(3) Encourage participants to think counterintuitively.

(4) Appraise innovations and the learning curve of participants, not the solutions per se.

(5) Do not follow the three phases in a sequential order. Allow for jumping back and forth through the identified stages of the process.

Through research by design new pathways are explored, people come up with innovative ideas and concepts that they would not encounter in a regular research or design process. The process is thought-provoking and binding. The results are not final spatial solutions, but merely conceptual innovations that could help to understand and deal with wicked problems. The proposed method should be refined, altered and revisited in practice. The different aspects of the method, be it concrete design tasks or more superficial elements of design processes, and interactivity or the way research and design are coupled or interwoven during the process, needs to be tested in practice-based design environments. The abstract three-staged method presented in this article can then be enriched, become more evidence-based in practical design projects and be more detailed and concretised. At the same time these practical applications of the method could inform the method in a way it becomes more universally used. However, it is difficult to predict a "final version" of the method, it seems logical that it will stay an abstract method, which needs to be adjusted depending the design task and the context, but at the same time the elaboration of the method will also lead to a more uniform approach, including more specified steps in the design process.

Conflicts of Interest: The author declares no conflict of interest.

\section{References}

1. Beck, U. The Reinvention of Polities: Towards a theory of reflexive modernization. In Reflexive Modernization: Polities, Tradition and Aesthetics in the Modern Social Order; Beck, U., Giddens, A., Lash, S., Eds.; Stanford University Press: Palo Alto, CA, USA, 1994.

2. Rittel, H.; Webber, M. Dilemmas in a General Theory of Planning. Policy Sci. 1973, 4, 155-169. [CrossRef]

3. Norton, B.G. Building Demand Models to Improve Environmental Policy Process. In Model-based Reasoning in Scientific Discovery; Magnani, L., Nersessian, N.J., Thagard, P., Eds.; Kluwer Academic/Plenum Publishers: New York, NY, USA, 1999.

4. De Jonge, J.M. Landscape Architecture between Politics and Science, an Integrative Perspective on Landscape Planning and Design in the Network Society. Ph.D. Thesis, Wageningen University, Wageningen, Amsterdam, The Netherlands, 2009.

5. Becker, H.; Jessen, J.; Sander, R. (Eds.) Ohne Leitbild? Städtebau in Deutscland und Europa; Krämer Verlag: Stuttgart/Zürich, Germany, 1998. (In German)

6. Rosemann, J. The Conditions of Research by Design in Practice. In Research by Design, Proceedings of the International Conference Proceedings A. Faculty of Architecture Delft University of Technology in Co-Operation with the EAAE/AEEA, Delft, The Netherlands, 1-3 November 2000; Van Ouwerkerk, M., Rosemann, J., Eds.; Delft University Press: Delft, The Netherlands, 2001; pp. 63-68.

7. Faste, T.; Faste, H. Demystifying "design research": Design is not research, research is design. In Proceedings of the Education Symposium (IDSA), Boston, MA, USA, 15-18 August 2012. 
8. Frieling, D. The Architectural Intervention. In Research by Design, Proeedings of the International Conference Proceedings A. Faculty of Architecture Delft University of Technology in Co-Operation with the EAAE/AEEA, Delft, The Netherlands, 1-3 November 2000; Van Ouwerkerk, M., Rosemann, J., Eds.; Delft University Press: Delft, The Netherlands, 2001; pp. 3-8.

9. Graafland, A. Contemporary Design Research. A material practice. In Research by Design, Proceedings of the International Conference Proceedings A. Faculty of Architecture Delft University of Technology in co-Operation with the EAAE/AEEA, Delft, The Netherlands, 1-3 November 2000; Van Ouwerkerk, M., Rosemann, J., Eds.; Delft University Press: Delft, The Netherlands, 2001; pp. 17-23.

10. De Queiroz Barbosa, E.R.; DeMeulder, B.; Gerrits, Y. Design Studio as a Process of Inquiry: The case of Studio Sao Paulo. Rev. Lusófona Arquit. Educ./Archit. Educ. J. 2014, 11, 241-254.

11. Nietzsche, F. Ueber Wahrheit und Lüge im Aussermoralischen Sinne. 1873. Available online: http:// gutenberg.spiegel.de/buch/-3243/1 (accessed on 18 May 2016).

12. Glanville, R. Research Design and Designing research. Des. Issues 1999, 15, 80-91. [CrossRef]

13. Pask, G. The architectural relevance of cybernetics. Archit. Des. 1969, 9, 494-496.

14. Wakkary, R. Framing Complexity, Design and Experience: A Reflective Analysis. Digit. Creativity 2005, 16, 65-78. [CrossRef]

15. Biggs, M. The Role of the Artefact in Art and Design Research. Int. J. Des. Sci. Technol. 2002, 10, $19-24$.

16. Laurel, B. (Ed.) Design Research: Methods and Perspectives; MIT Press: Cambridge, MA, USA, 2003.

17. Fallman, D. Why Research-Oriented Design Isn't Design-Oriented Research: On the Tensions between Design and Research in an Implicit Design Discipline. Knowl. Technol. Policy 2007, 20, 193-200. [CrossRef]

18. Koskinen, I.; Zimmerman, J.; Binder, T.; Redstrom, J.; Wensveen, S. Design Research through Practice; J. Morgan Kaufmann: Burlington, MA, USA, 2001.

19. Strand, D. Research in the Creative Arts; Report prepared by Canberra School of Arts for DEETYA; Department of Employment, Education, Training and Youth Affairs: Canberra, Australia, 1997.

20. De Jong, T.M. Study and Research Ubanism 2008; Department of Urbanism, Faculty of Architecture, Delft University of Technology: Delft, The Netherlands, 2008. Available online: http://taekemdejong. nl/Publications/Publicaties\%20Prof.\%20dr.\%20ir\%20T.M.\%20de\%20Jong.htm (accessed on 30 June 2016).

21. De Jong, T.M.; Van der Voordt, D.J.M. (Eds.) Ways to Study and Research Urban, Architectural and Technical Design; IOP Press BV: Amsterdam, The Netherlands, 2005.

22. Frayling, C. Research in art and design. R. Coll. Art Res. Pap. 1993, 1, 1-5.

23. Hauberg, J. Research by Design—A research strategy. Rev. Lusófona Arquit. Educ./Archit. Educ. J. 2011, 5, $46-56$.

24. Schreurs, J.; Maartens, M. Research by Design as Quality Enhancement; Dublin, U.C., Ed.; AESOP 5 The dream of a GREATER Europe; Vienna University of Technology/Osterreich. Kunst-und Kulturverlag: Vienna, Austria, 2005.

25. Cross, N. Designerly Ways of Knowing: Design Discipline versus Design Science. Des. Issues 2001, 17, 49-55. [CrossRef]

26. De Jong, T.M. Kleine Methodologie voor Ontwerpend Onderzoek; BOOM Uitgevers: Amsterdam, The Netherlands, 1992.

27. Binder, T.; Redström, J. Exemplary Design Research. In Proceedings of the Wonderground, Design Research Society International Conference, Lisbon, Portugal, 1-4 November 2006.

28. Swann, C. Action Research and the Practice of Design. Des. Issues 2002, 18, 49-61. [CrossRef]

29. Zimmerman, J.; Forlizzi, J.; Evenson, S. Research through Design as a Method for Interaction Design Research in HCI; ACM Press: New York, NY, USA, 2007; pp. 493-502.

30. Zimmerman, J.; Stolterman, E.; Forlizzi, J. An Analysis and Critique of Research through Design: Towards a Formalization of a Research Approach; ACM: New York, NY, USA, 2010; pp. 310-319.

31. Findeli, A. La Recherche-Projet: Une Méthode Pour la Recherche en Design. Available online: http://projekt. unimes.fr/files/2014/04/Findeli.2005.Recherche-projet.pdf (accessed on 8 September 2016). (In French)

32. Toeters, M.; Ten Bhömer, M.; Bottenberg, E.; Tomico, O.; Brinks, G. Research through Design: A way to drive innovative solutions in the field of smart textiles. Adv. Sci. Technol. 2013, 80, 112-117. [CrossRef]

33. Wilkie, A.; Gaver, W.; Hemment, D.; Giannachi, G. Creative assemblages: organisation and outputs of practice-led research. Leonardo 2010, 43, 98-99. [CrossRef] 
34. EAAE/AEEA Research Centre. Framework for Architectural Research. 2016. Available online: http: / / reseaaerch.wikidot.com/framework-for-architectural-research (accessed on 30 June 2016).

35. Maiki, F. Research by Design in Practice. In Proceedings of the International Conference Proceedings A, Delft, The Netherlands, 1-3 November 2000; Van Ouwerkerk, M., Rosemann, J., Eds.; Delft University Press: Delft, The Netherlands, 2001; pp. 63-68.

36. Simon, H.A. The Sciences of the Artificial; MIT Press: Cambridge, MA, USA, 1969.

37. Jonas, W. Research through DESIGN through Research-A Problem Statement and a Conceptual Sketch. In Proceedings of the Design Research Society International Conference, Lisbon, Portugal, 1-4 November 2006.

38. Godin, D.; Zahedi, M. Aspects of Research through Design: A Literature Review. In Proceedings of the Design Research Society Conference 2014, Umeå, Sweden, 16-19 June 2014.

39. Alexander, C. Notes on the Synthesis of Form; Harvard University Press: Cambridge, MA, USA, 1964.

40. Gregory, S.A. Design Science. In The Design Method; Gregory, S.A., Ed.; Butterworth: London, UK, 1966.

41. Simonsen, J.; Svabo, C.; Strandvad, S.M.; Samson, K.; Hertzum, M.; Hansen, O.E. (Eds.) Situated Design Methods; MIT Press: Cambridge, MA, USA, 2014.

42. Jonas, W. Research through DESIGN through research: A cybernetic model of designing design foundations. Kybernetes 2007, 36, 1362-1380.

43. Milburn, L.-A.S.; Brown, R.D. The relationship between research and design in landscape architecture. Lands. Urban Plan. 2003, 64, 47-66. [CrossRef]

44. Lima, A.G.G.; Buchler, D.M.; Biggs, M.A.R.; Perrone, R.A.C.; Zein, R.V.; De Santos, C.H.R.; Villac, M.I.; Bastos, M.A.J. Indicadores de Pesquisa Acadêmica Em Áreas de Prática Projetual. In V Projetar—Processos de Projeto: Teorias e Práticas; Escola de Engenharia-Universidade Federal de Minas Gerais: Belo Horizonte, Brazil, 2011; pp. 1-12. (In Portugese)

45. Basballe, D.A.; Halskov, K. Dynamics of Research through Design. In Proceedings of the Designing Interactive Systems, Newcastle, UK, 11-15 June 2012.

46. Roggema, R. Swarming landscapes, new pathways for resilient cities. In Proceedings of the 4th International Urban Design Conference "Resilience in Urban Design", Surfers Paradise, Australia, 21-23 September 2011.

47. Roggema, R. (Ed.) Swarming Landscapes: The Art of Designing for Climate Adaptation; Springer: Dordrecht, The Netherlands; Heidelberg, Germany; London, UK, 2012; p. 260.

48. Roggema, R. Swarm Planning: The Development of a Methodology to Deal with Climate Adaptation. Ph.D. Thesis, Delft University of Technology and Wageningen University and Research Centre Delft, Wageningen, The Netherlands, 2012.

49. Thomsen, M.R.; Tamke, M. Narratives of Making: Thinking practice led research in architecture. In Proceedings of the Conference Communicating (by) Design, Brussels, Belgium, 14-17 April 2009.

50. Schön, D. The Reflective Practitioner; Basic Books: New York, NY, USA, 1983.

51. Roggema, R.; Van den Dobbelsteen, A. Swarm Planning for Climate Change: An alternative pathway for resilience. J. Build. Res. Inf. 2012, 40, 606-624. [CrossRef]

52. Roggema, R.; Kabat, P.; Van den Dobbelsteen, A. Climate adaptation and spatial planning: Towards a new planning framework. SASBE 2012, 1, 29-58.

53. Waterman, R.E. Integrated Coastal Policy via Building with Nature. Ph.D. Thesis, Delft University of Technology, Delft, The Netherlands, 2010.

54. Armstrong, H. Design studios as research: An emerging paradigm in landscape architecture. Landsc. Rev. 1999, 5, 5-25.

55. Bowring, J. Research by design: the refereed studio. Landsc. Rev. 1997, 3, 54-55.

56. Finn, N.; Saputra, N.; Monaghan, T. Swell, the Design of Surge-Resilient Landscapes; RMIT University: Melbourne, Australia, 2012.

57. Powles Taig, W. Hobsons Bay Retreat; RMIT University: Melbourne, Australia, 2012.

58. Newman, J.; Al-Bazo, S.; Kendall, W.; Newton, J. Re-Burn; RMIT University: Melbourne, Australia, 2011.

59. Gunderson, L.H.; Holling, C.S. (Eds.) Panarchy: Understanding Transformations in Human and Natural Systems; Island Press: Washington, DC, USA, 2002.

60. Roggema, R.; Martin, J.; Arcari, P.; Clune, S.; Horne, R. Design-Led Decision Support: Process and Engagement; VCCCAR: Melbourne, Australia, 2013.

61. Lennertz, B.; Lutzenhiser, A. The Charrette Handbook. The Essential Guide for Accelerated, Collaborative Community Planning; APA: Chicago, IL, USA, 2006. 
62. Condon, P.M. Design Charrettes for Sustainable Communities; Island Press: Washington, DC, USA, 2008.

63. Roggema, R. (Ed.) The Design Charrette: Ways to Envision Sustainable Futures; Springer: Dordrecht, The Netherlands; Heidelberg, Germany; London, UK, 2013; p. 335.

64. Roggema, R.; Martin, J.; Horne, R. Sharing the Climate Adaptive Dream: The Benefits of the Charrette Approach. In Proceedings of the ANZRSAI Conference, Canberra, Australia, 6-9 December 2011.

65. Roggema, R.; Jones, R.; Soh, A.; Clune, S.; Hunter, S.; Barilla, A.; Cai, Z.; Tian, J.; Walsh, J. City of Greater Bendigo Design Charrette I, the Report; RMIT University, La Trobe University, Victoria University and VCCCAR: Melbourne, Australia, 2011.

66. Roggema, R.; Jones, R.; Clune, S.; Lindenbergh, D. Sea Lake Charrette, Dancing under the Stars; RMIT University, La Trobe University, Victoria University and VCCCAR: Melbourne, Australia, 2012.

67. Roggema, R.; Martin, J.; Horne, R.; Jones, R.; Hunter, S.; Soh, A.; Werner, J.; Clune, S. Design Brief Design Charrette I, City of Greater Bendigo; RMIT University, La Trobe University, Victoria University and VCCCAR: Melbourne, Australia, 2011.

68. Roggema, R.; Martin, J.; Horne, R.; Jones, R.; Soh, A.; Lindenbergh, D.; Clune, S. The Design Brief, Sea Lake Design Charrette I; RMIT University, La Trobe University, Victoria University and VCCCAR: Melbourne, Australia, 2012.

69. Clune, S.; Horne, R.; Roggema, R.; Martin, J.; Arcari, P. Sustainability Appraisals of Design-Led Responses to Climate Adaptation, Policy Brief; VCCCAR: Melbourne, Australia, 2013.

70. Roggema, R. Developing a Planning Theory for Wicked Problems: Swarm Planning. In Sustainable Energy Landscapes: Designing, Planning and Development; Stremke, S., van den Dobbelsteen, A., Eds.; Taylor and Francis: London, UK, 2012; pp. 161-185.

71. Roggema, R.; Vos, L.; Martin, J. Resourcing Local Communities for Climate Adaptive Designs in Victoria, Australia. Chin. J. Popul. Resour. Manag. 2014, 12, 210-226. [CrossRef]

72. Roggema, R.; Martin, J.; Vos, L. Governance of Climate Adaptation in Australia: Design Charrettes as Creative Tool for Participatory Action Research. In Action Research for Climate Change Adaptation: Developing and Applying Knowledge for Governance; Van Buuren, A., Eshuis, J., Van Vliet, M., Eds.; Routledge: London, UK, 2014; pp. 92-108.

73. Provincie Groningen. Omgevingsvisie Provincie Groningen 2016-2020; Provincie Groningen: Groningen, The Netherlands, 2016. (In Dutch)

74. Programmadirectie Hoogwaterbescherming. Projectenboek 2016, de Waterschappen en Rijkswaterstaat Zetten Door; Unie van Waterschappen en Rijkswaterstaat: Den Haag, The Netherlands, 2015. (In Dutch)

75. Roggema, R. City in Advance: Climate as Trigger for Adaptive Planning. In Proceedings of the International Conference for Urban Planning and Environment, Sydney, Australia, 24-27 July 2012.

76. Roggema, R. Thank God, the City is Complex. In Urban Regions under Change: Towards Social-Ecological Resilience; Hafencity University: Hamburg, Germany, 2014. 